\title{
PENGARUH IMPLEMENTASI MANAJEMEN KURIKULUM DAN KINERJA GURU TERHADAP PENINGKATAN MUTU LULUSAN DI SMK SWASTA SITI BANUN RANTAUPRAPAT
}

\author{
Khairul Anwar \\ Dosen Fakultas Ekonomi dan Bisnis, Universitas Labuhanbatu
}

\begin{abstract}
ABSTRAK
Penilitian ini bertujuan untuk mengetahui dan menganalisis pengaruh implementasi manajemen kurikulum dan kinerja guru terhadap mutu lulusan di SMK Swasta siti Banun Rantauprapat. Penelitian ini menerapkan metode explanatory survey. Objek pnelitian ini adalah SMK Swasta Siti Banun Rantuprapat. Populasi dan sampel adalah seluruh Guru dan pegawai tata usaha SMK siti Banun Rantauprapat yang berjumlah 80 orang. Hasil pnelitian menunjukkan bahwa: 1) ditemukan pengaruh signifikan dari implementasi manajemen kurikulum terhadap peningkatan mutu lulusan di SMK siti Banun Rantuprapat dengan fhitung $0.059>$ Pvalue 0,021. 2) ditemukan pengaruh signifikan dari kinerja Guru terhadap peningkatan mutu lulusan di SMK Siti Banun Rantauprapat di buktikan dengan nilai fhitung $0.989>$ Pvalue 0,021.dan 3) terlihat pengaruh signifikan dari implementasi manajemen kurikulum dan kinerja guru secara bersamaan terhadap penigkatan mutu lulusan di SMK Siti Banun Rantauprapat Hal ini berdasarkan hasil analisis data yang menunjukkan nilai fhitung $0.989>$ Pvalue 0,021 .
\end{abstract}

Kata Kunci: Implamentasi Manajemen Kurikulum, Kinerja Guru, Mutu Lulusan

\section{BAB I :PENDAHULUAN}

\subsection{Latar Belakang Penelitian}

Pendidikan merupakan langkah penting dalam membangun negara ini. Hal tersebut dibuktikan dalam pembukaan UUD 1945 yang berbunyi "dengan mencerdaskan kehidupan bangsa". Sekolah adalah lembaga pendidikan yang memiliki fungsi untuk meningkatkan sumber daya manusia. Sekolah merupakan lingkungan yang dibentuk untuk memenuhi kebutuhan manusia berupa pendidikan.

Sekolah merupakan organisasi pendidikan yang di dalamnya terdapat berbagai SDM yang berperan aktif dalam memajukan pendidikan bangsa. Perkembangan Dalam Dunia Pendidikan cenderung memberikan tantangan-tantangan dan permasalahan baru. Keadaan tersebut akan berimbas pada tugas-tugas pengelola pendidikan. Sehingga diperlukan implementasi manajemen kurikulum dengan maksimal dan kinerja guru selaku aktor terpenting terhadap peningkatan mutu lulusan sekolah.

Sekolah tidak saja membutuhkan implementasi manajemen kurikulum dengan maksimal, tetapi juga memerlukan kinerja guru yang baik. Program pengembangan bagi guru adalah salah satu upaya untuk meningkatkan profesionalitas kinerja guru. Guru merupakan media utama bagi pembelajaran, yang bertanggungjawab dan memberikan sumbangan pada pengembangan potensi siswa (Uwes, 1999:38).

Kurikulum bersifat dinamis, mengikuti perkembangan real di masyarakat. Ilmu dan Teknologi berubah, kompleksitas permasalahan di masyarakat juga berubah dan tantangan-tantangan yang dihadapi oleh siswa sebagai bagian dari masyarakat juga berubah. Seiring dengan perubahan-perubahan itu, juga ditemukan pemikiran-pemikiran 
baru di dunia pendidikan. Lalu muncul pengembangan kurikulum. Setidaknya ada enam faktor yang menentukan terjadinya perubahan kurikulum. Pertama, Filsafat kita kenal terdiri dari beberapa aliran yaitu perenialisme, esensialisme, eksistensialisme, progresivisme, dan rekonstruktivisme. Sekarang ini ada beberapa kecenderungan di beberapa Negara, termasuk Indonesia beraliran filsafat rekonstruksivisme. Berdasarkan aliran ini, manusia belajar dengan cara mengkonstruksi pengetahuan yang dimilikinya menjadi pengetahuan baru. Sejak pemberlakukan kurikulum berbasis kompetensi (KBK) setidaknya aliran ini sudah menjadi landasan.

Salah satu yang sangat urgen dalam dunia pendidikan salah satunya Mutu Lulusan. Mutu merupakan bentuk perubahan dimana perubahan tersebut diperlukan waktu yang relatif panjang. Seperti yang dijelaskan oleh Sallis (2012:211) bahwa mutu tidak terjadi begitu saja, harus direncanakan. Mutu harus menjadi bagian penting dari strategi institusi, dan harus didekati secara sistematis dengan menggunakan proses perencanaan strategis. Oleh karena itu, untuk mewujudkan suatu lembaga pendidikan yang bermutu diawali dari peningkatan kualitas sumber dayanya, khususnya tenaga pendidik yang memegang peranan penting dalam membentuk peserta didik yang bermutu.

Rendahnya mutu lulusan dapat dilihat dari indikator-indikator seperti presentasi lulusan yang kecil diukur dari hasil ujian nasional, presentasi lulusan yang kecil diukur dari sedikitnya jumlah lulusan yang diterima di perguruan tinggi favorit dan presentasi yang kecil diukur dari sedikitnya jumlah lulusan yang diterima bekerja di pasar kerja domestik maupun pasar kerja luar negeri.

Peningkatan mutu lulusan dari waktu ke waktu selalu diupayakan perbaikannya di semua tingkatan, baik pada pendidikan di tingkat dasar, menengah maupun pendidikan di perguruan tinggi. Perbaikan mutu itu dilaksanakan di segala bidang antara lain sarana/prasarana, kurikulum, pendidik/guru. Implementasi manajemen kurikulum dan kinerja guru memberikan dampak yang besar bagi peningkatan mutu lulusan .

Berdasarkan penjelasan di atas, maka penulis tertarik untuk mengajukan judul penelitian "Pengaruh Implementasi manajemen kurikulum dan Kinerja Guru Terhadap Peningkatan Mutu Lulusan Di SMK Swasta Siti Banun Rantau Parapat Tahun Pelajaran 2018-2019".

\subsection{Rumusan Masalah}

Berdasarkan uraian permasalahan, maka penulis mengemukakan pernyataan masalah (Problem Statement) yaitu Mutu Lulusan masih rendah yang diduga disebabkan oleh belum diimplementasikannya kurikulum dengan maksimal serta kinerja guru yang diduga masih tergolong rendah.

\subsection{Maksud dan Tujuan Penelitian}

\subsubsection{Maksud Penelitian}

Maksud penelitian ini adalah untuk mengetahui dan menganalisis pengaruh Implementasi manajemen kurikulum dan Kinerja Guru terhadap Mutu Lulusan di SMK Swasta Siti Banun Rantau Parapat.

\subsubsection{Tujuan Penelitian}

Penelitian ini bertujuan untuk:

1. Untuk mengetahui dan menganalisis pengaruh Implementasi Manajemen Kurikulum dan Kinerja Guru secara simultan terhadap Peningkatan Mutu Lulusan di SMK Swata Siti Banun Rantau Parapat. 
2. Untuk mengetahui dan menganalisis pengaruh Implementasi Manajemen Kurikulum terhadap Mutu Lulusan secara parsial melalui faktor-faktornya di SMK Swasta Siti Banun Rantau Parapat.

3. Untuk mengetahui dan menganalisis pengaruh Kinerja Guru terhadap Mutu Lulusan secara parsial melalui dimensi-dimensinya di SMK Siti Banun Rantau Parapat.

\subsection{Kegunaan Penelitian}

\section{a. Kegunaan Teoritis.Praktis}

Penelitian ini diharapkan dapat memperluas wawasan ilmu pengetahuan di bidang administrasi pada umumnya dan administrasi pendidikan khususnya, Penelitian ini diharapkan dapat menjadi bahan masukan bagi pihak-pihak yang berkepentingan khususnya sekolah agar dapat mengimplementasikan kurikulum dengan baik serta secara bersamaan dapat meningkatkan kinerja guru agar mutu lulusan di SMK Siti Banun Rantau Parapat meningkat.

\section{BAB II KAJIAN PUSTAKA}

\subsection{Hasil Penelitian Azhari}

Azhari (2017) melakukan penelitian yang berjudul manajemen kurikulum dalam peningkatan mutu pendidikan. Dalam penelitian ini dijelaskan bahwa implementasi mejemen kurikulum sangat berperan signifikan dalam menentukan mutu lulusan. Karena bidang garapannya meliputi perencanaan, pengorganisasian, penggerakan, pengawasan atau evaluasi dan pemberdayaan segala sumber daya yang ada. Oleh sebab itu pendidikan tidak akan berhasil tanpa diatur sesuai dengan fungsi dan peran masing-masing secara efektif dan efisien.

Metode penelitian yang digunakan adalah metode kualitatif dengan menggunakan observasi, wawancara dan studi dokumentasi sebagai teknik pengumpuluan data penelitian. Teknik analisis data yang dilakukan terdiri dari alur reduksi data, alur penyajian data, alur penarikan kesimpulan.

\subsection{Hasil Penelitian Niken}

Niken (2017) melakukan penelitian tentang Kinerja Guru dalam meningkatkan mutu pendidikan melalui Kurikulum 2013. Penelitian ini bertujuan menjelaskan upaya kinerja guru dan kendala yang di hadapi terhadap usaha peningkatan mutu lulusan melaui kurikulum 2013.

\subsection{Relevansi dengan Hasil Penelitian Terdahulu}

Setelah memaparkan hasil penelitian dari Azhari (2017) dan Niken (2017), relevansi atau keterkaitan antara hasil penelitian di atas dengan penelitian yang dilakukan oleh penulis dapat dilihat pada tabel 2.1 berikut ini.

Tabel 2.1 Relevansi Hasil Penelitian Terdahulu dengan Tesis Penulis.

\begin{tabular}{|l|l|l|lr|l|}
\hline No. & Nama & Teori Penelitian & \multicolumn{2}{l|}{ Teori yang digunakan } & Persamaan/Perbedaan \\
& Peneliti/Judul & Terdahulu & Penulis & \\
\hline 1. & Azhari (2017) & Teori & Teori Implementasi & Sama-sama meneliti tentang \\
& Manajemen & Manajemen dan & mejemen kurikulum & Implementasi mejemen \\
& Kurikulum & Implementasi & menurut Rusman & kurikulum Ram \\
& dalam & mejemen & $(2009: 18)$ dan Teori & meningkatkan mutu lulusan. \\
& Peningkatan & kurikulum dari & & & \\
\hline
\end{tabular}




\begin{tabular}{|c|c|c|c|c|}
\hline & $\begin{array}{l}\text { Mutu } \\
\text { Pendidikan }\end{array}$ & $\begin{array}{l}\text { Bryan } \\
\text { Independent } \\
\text { School }(2015: 6)\end{array}$ & $\begin{array}{l}\text { Kinerja Guru menurut } \\
\text { Mahmudi (2007:16) }\end{array}$ & $\begin{array}{l}\text { Teori yang digunakan } \\
\text { berbeda dan lokus } \\
\text { penelitian yang berbeda. }\end{array}$ \\
\hline 2. & $\begin{array}{l}\text { Niken (2017) } \\
\text { Kinerja Guru } \\
\text { dalam } \\
\text { Meningkatkan } \\
\text { Mutu } \\
\text { Pendidikan } \\
\text { Melalui } \\
\text { Kurikulum } \\
2013\end{array}$ & $\begin{array}{l}\text { Teori Kinerja } \\
\text { Guru menurut } \\
\text { Mulyasa } \\
(2013: 88) \text { dan } \\
\text { Teori tentang } \\
\text { Mutu } \\
\text { Pendidikan } \\
\text { menurut Usman } \\
(2006: 406)\end{array}$ & $\begin{array}{l}\text { Teori Implementasi } \\
\text { mejemen kurikulum } \\
\text { menurut Rusman } \\
(2009: 18) \text { dan Teori } \\
\text { Kinerja Guru menurut } \\
\text { Mahmudi (2007:16) }\end{array}$ & $\begin{array}{l}\text { Sama-sama mengkaji } \\
\text { tentang Kinerja Guru dalam } \\
\text { Meningkatkan Mutu } \\
\text { Lulusan. } \\
\text { Menggunakan teori yang } \\
\text { berbeda mengenai Kinerja } \\
\text { Guru dan teori berbeda } \\
\text { mengenai mutu lulusan. } \\
\text { Lokus penelitian berbeda. }\end{array}$ \\
\hline
\end{tabular}

Sumber: diolah penulis (2019).

Setelah memahami berbagai perbedaan antara penelitian terdahulu dengan penelitian yang dilakukan oleh penulis, maka terlihat keaslian penelitian ini, sehingga penelitian terdahulu menjadi daya dukung dan memberi inspiriasi bagi penulis untuk menghasilkan penelitian yang berkualitas dan orisinil.

\subsection{Implementasi mejemen kurikulum}

Kurikulum merupakan sebuah produk kebijakan-kebijakan yang dikeluarkan oleh pemerintah, dalam hal ini kementerian pendidikan, yang merupakan suatu kerangka acuan, dasar/landasan bagi setiap institusi terkait yang melaksanakan kegiatan pendidikan. Seperti yang telah dijelaskan sebelumnya bahwa kebijakan-kebijakan hanya akan menjadi arsip yang tersimpan rapi jika tidak diimplementasikan. Oleh karena itu, pada bagian ini akan dijelaskan pendapat-pendapat ahli mengenai implementasi mejemen kurikulum.

Menurut Suharsono (2003:120) implementasi merupakan suatu tindakan atau upaya untuk melaksanakan penegakan aturan agar sesuai dengan peraturan yang berlaku. Implementasi adalah suatu tindakan atau pelaksanaan dari sebuah rencana yang sudah disusun secara matang dan terperinci. Implementasi biasanya dilakukan setelah perencanaan sudah dianggap fix. Implementasi merupakan tahapan pelaksanaan dari apa yang sudah di rencanakan pada tahap perencananaan. Dalam hal ini adalah melaksanakan tahapan-tahapan yang sudah di rencanakan dalam kurikulum sehingga nilai-nilai atau gagasan-gagasan yang terkandung dalamnya dapat di transfer dengan baik.

Pendekatan Kurikulum menurut Nurdin dan Usman dijelaskan bahwa pendekatan pertama, menggambarkan implementasi itu dilakukan sebelum penyebaran (desiminasi) desain kurikulum. Maksud proses dalam hal tersebut adalah memberkan penjelasan tujuan program dan menjelaskan sumber- sumber baru dan mendemonstrasikan metode pengajaran yang digunakan. Pendekatan kedua merupakan bentuk penekanan dan penyempurnaan dan hubungan antara guru dan pengembang kurikulum.pengembang melakukan kajian kembali dan memastikan isi materi program tersebut sudah sesuai dengan kebutuhan pendidikan.

Jadi, implementasi mejemen kurikulum merupakan bentuk aktualisasi dari kurikulum yang telah direncanakan. Bentuk implementasi mejemen kurikulum adalah kegiatan pembelajaran yang dilakukan guru bersama siswa untuk mencapai tujuan kurikulum yang telah ditetapkan. Muara keberhasilan kurikulum secara aktual akan ditentukan oleh implementasi mejemen kurikulum di lapangan (Rusman, 2009:18).

\subsection{Kinerja Guru}

Konsep kinerja menurut Widodo (2005:78) menyatakan bahwa kinerja adalah melakukan suatu kegiatan dan menyempurnakannya sesuai dengan tanggungjawabnya 
dengan hasil seperti yang diharapkan. Maksud pengertian ini menjelaskan bahwa kinerja merupakan hasil kerja sesuai dengan wewenang dan tanggunjawabnya. Selanjutnya Sedarmayanti (2009:50) mengemukakan bahwa kinerja mempunyai hubungan erat dengan masalah produktivitas karena merupakan indikator dalam menentukan bagaimana usaha untuk mencapai tingkat produktivitas yang tinggi dalam suatu organisasi.

Kinerja merupakan hal penting dalam kegiatan manajemen ataupun administrasi, karena ini dapat dijadikan umpan balik bagi para pengelola dan para pembuat keputusan. Dengan kata lain kinerja diartikan sebagai pencapaian penugasan kewajiban dan outcome yang dihasilkan pada fungsi jabatan atau aktivitas jabatan selama periode tertentu. Kinerja bukan hanya menyangkut kuantitas atau sejumlah hasil yang bisa dihitung, tetapi juga termasuk kualitas atau mutu pekerjaan.

Faktor-faktor yang dijadikan ukuran kinerja menurut pendapat Mitchell dalam Sedarmayanti (2001:51) adalah faktor kemampuan (ability), faktor motivasi (motivation) yang dirumuskan sebagai berikut:

\section{Human Performance $=$ Ability + Motivation}

Kedua faktor ini merupakan prasyarat dari ukuran kinerja seorang pegawai dalam melaksanakan pekerjaan sebagai tanggungjawab terhadap tugas-tugasnya. Selanjutnya Mitchell mengemukakan mengenai pengukuran kinerja berdasarkan pada aspek-aspek kinerja sebagai berikut.
a. Kualitas kerja
b. Ketepatan waktu
c. Inisiatif
d. Kemampuan
e. Komunikasi

Kelima aspek tersebut merupakan standar umum mengukur kinerja pegawai pada berbagai institusi, baik pemerintah maupun swasta. Menurut Moeheriono (2009:61) melalui model mitra-lawyer, mengukur kinerja pegawai (individu) dipengaruhi oleh 7 faktor sebagai berikut:

1. Harapan mengenai imbalan

2. Dorongan

3. Kemampuan

4. Kebutuhan dan sifat

5. Persepsi terhadap tugas

6. Imbalan internal dan eksternal

7. Persepsi terhadap tingkat imbalan dan keputusan kerja.

Ketujuh faktor tersebut merupakan standar pengukuran kinerja seseorang atau sekelompok orang di dalam suatu organisasi baik secara kuantitatif maupun kualitatif, sesuai dengan kewenangan, tugas dan tanggungjawab pegawai yang 2.6. Peningkatan

\section{Mutu Lulusan}

Permasalahan bngsa ssat ini sangat erat kaitannya densgn Mutu lulusan yang rendah dimana mutu lulusan yang rendah diakibatkan oleh mutu pendidikan yang rendah. Berbagai upaya dilakukan pemerintah dalam meningkatkan mutu lulusan missal upaya meningkatkan kompetensi guru. Upaya pemberian tunjangan guru professional dalam rangka upaya peningkatan kinerja guru, peningkatan infrastruktur pendidikan.peningkatan manajemnen sekolah dan usaha pengembanagn kurikulum. Namun, berbagai indikator mutu pendidikan belum menunjukkan adanya peningkatan yang berarti. Sebagian sekolah, terutama di kota-kota besar menunjukkan peningkatan mutu yang menjanjikan, sebagian lagi masih dalam kondisi memperihatinkan, terutama sekolah-sekolah yang berada di daerah-daerah masih dalam kondisi jauh dari yang diharapkan.

\section{BAB III: OBYEK DAN METODE PENELITIAN}




\subsection{Obyek Penelitian}

Obyek penelitian adalah wilayah atau daerah penelitian di mana penulis melakukan penelitian. Adapun obyek penelitiannya adalah Sekolah Menengah Kejuruan Siti Banun Rantau Parapat. Alasan penulis memilih lokasi penelitian tersebut karena dalam penyelenggaraan pendidikan terutama yang berkaitan dengan hasil lulusannya masih rendah berdasarkan observasi awal yang telah dilaksanakan sebelumnya. Permasalahan tersebut diduga terjadi karena belum maksimalnya Implementasi menejemen kurikulum dan Kinerja Guru yang masih cenderung rendah sehingga berujung pada rendahnya Mutu Lulusan di SMK Siti Banun Rantau Parapat.

\subsection{Metode Penelitian}

Metode penelitian yang digunakan dalam penelitian ini adalah explanatory survey. Pemilihan metode ini didasarkan pertimbangan bahwa metode ini tidak hanya menjelaskan atau menggambarkan fakta empiris di lapangan melainkan juga akan menjelaskan analisis pengaruh. Seperti yang dijelaskan oleh Singarimbun (1982:4) bahwa penelitian explanatory atau Confirmatory menyoroti hubungan antara variable-variabel penelitian dan menguji hipotesis yang telah dirumuskan sebelumnya.

Berdasarkan teori yang dikemukakan tersebut, maka metode explanatory survery merupakan metode penelitian yang menyoroti hubungan atau pengaruh variable-variabel penelitian dengan menguji hipotesis yang telah dikemukakan pada uraian sebelumnya. Dengan demikian selain menggambarkan kondisi obyek yang dikaji, penelitian ini juga menjelaskan hubungan-hubungan dari beberapa variabel, menguji hipotesis-hipotesis, membuat prediksi maupun implikasi.

Berdasarkan metode penelitian tersebut, maka metode yang digunakan dalam penelitian ini adalah metode explanatory survey, yaitu penelitian yang menyoroti hubungan atau pengaruh antara variabel-variabel penelitian dengan menguji hipotesis yang telah dirumuskan sebelumnya.

\subsection{Populasi Penelitian dan Teknik Penarikan Sampel}

Populasi dalam penelitian ini adalah seluruh guru dan pegawai tata usaha Sekolah Menengah Kejuruan Siti Banun Rantau Parapat dengan jumlah populasi 65 orang, yang akan mempersepsikan implementasi menejemen kurikulum dan kinerja guru di SMK Siti Banun Rantau Parapat,dilakukan sampel jenuh (sensus)

\subsection{Teknik Pengambilan Sampel}

Untuk menentukan sampel populasi dari guru dan staf administrasi di Sekolah Menengah Kejuruan Siti Banun Rantau Parapat, maka digunakan teknik Stratified Random Sampling.

\section{BAB IV:HASIL PENELITIAN DAN PEMBAHASAN}

\subsection{Hasil Penelitian}

Variabel pada penelitian ini terdiri dari tiga variabel, yaitu variable implementasi menejemen kurikulum dan kinerja guru sebagai variabel bebas yang diberi simbol $X_{1}$ dan $\mathrm{X}_{2}$ dan peningkatan mutu lulusan sebagai variabel terikat yang ditandai dengan simbol $\mathrm{Y}$. Penelitian ini dilakukan dengan cara menganalisis variabel implementasi manajemen kurikulum dan kinerja guru yang diduga memiliki pengaruh besar terhadap peningkatan mutu lulusan, rangkaian penelitian yang dilakukan sebagai suatu studi kasus di SMK SWASTA SITI BANUN Rantau Prapat.wawancara. Sebelum dilakukan analisis lebih lanjut maka diperlukan suatu pengujian validitas dan reliabilitas dari angket dan pertanyaan wawancara pada penelitian ini.

\subsection{Pengujian Hipotesis/Pembahasan Hasil Penelitian}


Korelasi adalah suatu ukuran derajat bervariasinya kedua variabel (variabel bebas dan terikat) secara bersama-sama atau ukuran keeratan hubungan antara dua variabel. Korelasi antara variabel implementasi manajemen kurikulum (X1), Kinerja Guru (X2) dan variabel peningkatan mutu lulusan (Y) dapat dilihat pada tabel berikut ini.

Tabel 4.14 Korelasi antara variabel X1, X2 dan Y

\begin{tabular}{lrrr}
\hline & \multicolumn{1}{c}{$X 1$} & $X 2$ & $Y$ \\
\hline $\mathrm{X} 1$ & 1 & & \\
$\mathrm{X} 2$ & 0.200266 & 1 & \\
$\mathrm{Y}$ & 0.05962 & 0.989939 & 1 \\
\hline
\end{tabular}

Tabel di atas menunjukkan bahwa terdapat korelasi antara variabel implementasi manajemen kurikulum (X1) dengan variabel Kinerja Guru (X2) yaitu sebesar 0.200. Korelasi antara variabel implementasi manajemen kurikulum (X1) terhadap variabel peningkatan mutu lulusan (Y) sebesar 0.059 dan korelasi antara variabel kinerja guru (X2) terhadap variabel peningkatan lulusan (Y) sebesar 0.989 .

Selanjutnya untuk menguji apakah terdapat pengaruh antara implementasi manajemen kurikulum dan kinerja guru terhadap peningkatan mutu lulusan dapat dilihat pada tabel berikut.

Tabel 4.15 Analisis Varian (ANOVA)

\begin{tabular}{lcccccc} 
ANOVA & \multicolumn{1}{c}{ Source of } \\
$\quad$ Variation & $S S$ & $d f$ & $M S$ & $F$ & P-value & $F$ crit \\
\hline Between & & & & & & \\
Groups & 129266.7 & 2 & 64633.33 & 7.82528 & 0.021284 & 5.143253 \\
Within Groups & 49557.33 & 6 & 8259.556 & & & \\
& & & & & & \\
Total & 178824 & 8 & & & & \\
\hline
\end{tabular}

Berdasarkan perhitungan data yang dilakukan, diperoleh nilai Fhitung sebesar 7.825 dimana untuk untuk kriteria penolakan $\mathrm{H}_{0}$ cukup melihat nilai dari $\mathrm{P}$-value yang diperoleh sebesar 0.021, yang berarti dengan $\alpha$ lebih kecil dari 5\% masih menunjukkan pengaruh yang signifikan (artinya terdapat pengaruh yang kuat antara variabel implementasi manajemen kurikulum dan kinerja guru terhadap peningkatan mutu lulusan).

$\mathrm{PYX}_{1} \quad=$ Besarnya hubungan variabel $\mathrm{X}_{1}$ dengan $\mathrm{Y}=0.059$

$\mathrm{PYX}_{2} \quad=$ Besarnya hubungan variabel $\mathrm{X}_{2}$ dengan $\mathrm{Y}=0.989$

$\mathrm{RX}_{1} \mathrm{X}_{2} \quad=$ Hubungan antara $\mathrm{X}_{1}$ dan $\mathrm{X}_{2}=0.200$

\subsection{Pengaruh Implementasi manajemen Kurikulum terhadap Peningkatan Mutu Lulusan}

Berdasarkan data yang diperoleh pada penelitian ini, diketahui bahwa Implementasi manajemen Kurikulum berpengaruh signifikan terhadap peningkatan mutu lulusan. Hal ini dibuktikan dengan perolehan data yang menunjukkan bahwa besarnya pengaruh variabel implementasi manajemen kurikulum (X1) terhadap peningkatan mutu lulusan (Y) sebesar 0.059. Adapun model formulasi hipotesis untuk rumusan masalah pertama adalah:
$\mathrm{H}_{0} \quad: \quad \mathrm{PYX} 1 \leq 0$ (hipotesis ditolak)
Ha $\quad$ : $\quad$ PYX1 $>0$ (hipotesis diterima)

Berdasarkan ketentuan di atas, dapat disimpulkan bahwa hipotesis diterima karena terdapat pengaruh implementasi manajemen kurikulum terhadap peningkatan mutu lulusan dengan nilai Fhitung sebesar 0.059 dengan $\mathrm{P}$ value sebesar 0.021 , ini berarti Fhitung $>\mathrm{P}$ value. Sehingga dapat disimpulkan bahwa implementasi manajemen kurikulum 
berpengaruh signifikan terhadap peningkatan mutu lulusan di SMK Swasta Siti Banun Rantau Prapat.

\subsection{Pengaruh Kinerja Guru terhadap Peningkatan Mutu Lulusan}

Sesuai dengan perolehan data penelitian ini yang menunjukkan bahwa nilai $\mathrm{PYX}_{2}$ adalah sebesar 0.989. Ini berarti bahwa terdapat pengaruh kinerja guru (X2) terhadap peningkatan mutu lulusan (Y). Adapun model formulasi hipotesis untuk rumusan masalah kedua dalam penelitian ini adalah:

$\mathrm{H}_{0} \quad: \quad$ PYX2 $\leq 0$ (hipotesis ditolak)

Ha $\quad$ : $\quad$ PYX2 $>0$ (hipotesis diterima)

Berdasarkan ketentuan tersebut, dapat disimpulkan bahwa hipotesis diterima karena terdapat pengaruh kinerja guru terhadap peningkatan mutu lulusan dengan nilai Fhitung sebesar 0,989 dengan $P$ value sebesar 0.021 yang berarti bahwa kinerja guru berpengaruh signifikan terhadap peningkatan mutu lulusan di SMK Swasta Siti Banun Rantau Prapat karena Fhitung (0.989) > P value (0.021).

\subsection{Pengaruh Implementasi manajemen Kurikulum dan Kinerja Guru terhadap Peningkatan Mutu Lulusans}

Berdasarkan penjelasan sebelumnya, diketahui bahwa masing-masing variabel bebas yang berupa variabel implementasi manajemen kurikulum (X1) dan variabel kinerja guru (X2) memiliki pengaruh yang signifikan terhadap peningkatan mutu lulusan di SMK Swasta Siti Banun Rantau Prapat. Kemudian, rumusan masalah yang ketiga dalam penelitian ini merupakan penjabaran mengenai pengaruh kedua variabel bebas tersebut secara bersamaan terhadap variabel terikat penelitian.

Sesuai dengan pengolahan data yang telah dilakukan oleh peneliti, diperoleh hasil bahwa pengaruh implementasi manajemen kurikulum dan kinerja guru secara bersamaan terhadap peningkatan mutu lulusan adalah sebesar 0.200. Adapun model formulasi hipotesis untuk rumusan masalah kedua dalam penelitian ini adalah:

$\mathrm{H}_{0} \quad: \quad$ PYX1X2 $\leq 0$ (hipotesis ditolak)

Ha $\quad$ : $\quad$ PYX1X2 $>0$ (hipotesis diterima)

Berdasarkan model formulasi di atas, maka dapat disimpulkan bahwa hipotesis diterima karena nilai Fhitung X1X2 adalah $0.200>0$. Selanjutnya nilai Fhitung (0.200) tersebut juga lebih besar dibandingkan dengan nilai $\mathrm{P}$ value $(0.021)$ sehingga dapat disimpulkan bahwa implementasi manajemen kurikulum dan kinerja guru secara bersamaan berpengaruh signifikan terhadap peningkatan mutu lulusan di SMK Swasta Siti Banun Rantau Prapat.

\section{BAB V:KESIMPULAN DAN SARAN}

\subsection{Kesimpulan}

Setelah analisis hasil penelitian mengenai pengaruh implementasi manajemen kurikulum dan kinerja guru terhadap peningkatan mutu lulusan di SMK Swasta Siti Banun Rantau Prapat, dapat disimpulkan menjadi beberapa poin sebagai berikut.

1. Terdapat pengaruh yang signifikan dari implementasi manajemen kurikulum terhadap peningkatan mutu lulusan di SMK Swasta Siti Banun Rantau Prapat.

2. Terdapat pengaruh yang signifikan dari kinerja guru terhadap peningkatan mutu lulusan di SMK Swasta Siti Banun Rantau Prapat.

3. Terdapat pengaruh yang signifikan dari implementasi majemen kurikulum dan kinerja guru secara bersamaan terhadap peningkatan mutu lulusan di SMK Swasta Siti Banun Rantau Prapat.

\subsection{Saran}

Berdasarkan kesimpulan hasil penelitian ini, selanjutnya perlu disampaikan beberapa saran sebagai kontribusi hasil penelitian mengenai pengaruh implementasi 
manajemen kurikulum dan kinerja guru terhadap peningkatan mutu lulusan. Saran-saran tersebut dikemukakan sebagai berikut.

1. Kepada para stakeholder maupun pimpinan sekolah agar dapat memaksimalkan implementasi manajemen kurikulum di sekolah-sekolah agar mutu lulusan yang dihasilkan semakin meningkat.Pimpinan-pimpinan sekolah maupun kedinasan terkait diharapkan dapat melakukan evaluasi dan masukan terhadap kinerja guru dengan rutin dan maksimal agar kualitas kinerja guru semakin meningkat.

2. Bagi para guru, disarankan untuk terus melakukan pembaharuan (update) pengetahuan mengenai kebijakan-kebijakan kurikulum yang berlaku agar lebih siap dalam proses perencanaan, pelaksanaan dan penilaian pembelajaran yang dilakukan di dalam kelas.

3. Guru juga diharapkan untuk dapat dengan baik melaksanakan pembelajaran yang sesuai dengan kurikulum yang berlaku agar kompetensi-kompetensi belajar yang menjadi target pembelajaran dapat dicapai dengan baik pula.

4. Bagi peneliti lain, disarankan untuk terus melakukan penelitian di bidang yang serupa terkait dengan peningkatan mutu lulusan agar kajian yang relevan menjadi semakin kaya dan semakin bermanfaat bagi peningkatan mutu lulusan siswa di sekolah-sekolah di Indonesia.

\section{DAFTAR PUSTAKA}

Albrow, Martin. 1989. Birokrasi (terjemahan Rusli Karim). Yogyakarta: Grafiti.

Asmi E, dan Sahuri, C. Pelayanan Sekolah untuk Meningkatkan Kualitas Pendidik. Jurnal Kebijakan Publik, 4(1). hlm. 51.

Boediono, dan Koster, W. 2004. Teori dan Aplikasi Statistika dan Probabilitas. Bandung: PT. Remaja Rosdakarya.

Fadhilah, M. 2014. Implementasi Kurikulum 2013. Yogyakarta: Ar-Ruz Media.

George, E.C. 1980. Implementing Public Policy. Washington DC: Conressional Quarterly Press.

Hamalik, O. 1991. Pendidikan Pendidik. Bandung: Remaja Rosdakarya.

Hasbullah. 2005. Otonomi Pendidikan. Jakarta: PT. Raja Grafindo Persada.

Islamy, dan Irfan, M. 2004. Prinsip-prinsip Perumusan Kebijakan Negara. Jakarta: Bumi Aksara.

Kosasih, E. 2014. Strategi Belajar dan Pembelajaran Implementasi Kurikulum 2013. Bandung:Yrama Widya.

Kurniasih, I, dan Sani, B. 2016. Implementasi Kurikulum 2013 Konsep dan Penerapan. Jakarta: Kata Pena.

Mufidah, L. 2009. Aktualisasi TQM dalam Meningkatkan Profesionalisme Guru di Lembaga Pendidikan Islam. Jurnal Tadris, 4(1). hlm. 91.

Muhaimin, dkk. 2008. Pengembangan Model Kurikulum Tingkat Satuan Pendidikan (KTSP) pada Sekolah dan Madrasah. Jakarta: Rajagrafindo Persada.

Mulyasa, E. 2007. Menjadi Kepala Sekolah Profesional. Bandung: Remaja Rosdakarya.

Mulyoto. 2013. Strategi Pembelajaran di Era Kurikulum. Jakarta: Kata Pena.

Osborne, dan Gaebler, T. 1999. Mewirausahakan Birokrasi. Jakarta: PT. Pustaka Binaman Presindo.

Peraturan Pemerintah Pendidikan Nasional Nomor 19 Tahun 2007

Rusman. 2009. Manajemen Kurikulum. Jakarta:Rajawali Press.

Sallis, E. 2012. Total Quality Management in Education: Manajemen Mutu Pendidikan, terj. Ahmad Ali Riyadi dan Fahrurrozi. Cet. XVI, Jogjakarta: IRCiSoD.

Suharsono. 2003. Dasar-dasar Kebijakan Publik. Yogyakarta: PT. Ombak.

Undang-undang SISDIKNAS No. 20 Th. 2003. Jakarta: Sinar Grafika.

Uwes, S. 1999. Manajemen Pengembangan Mutu Dosen. Jakarta: Logos Wacana Ilmu.

Wylie, P, dan Grothe, M. 1997. Karyawan Bermasalah, Kiat Meningkatkan Kinerja Mereka. Jakarta: Erlangga. 